\title{
WOMEN IN HIGHER EDUCATION INSTITUTIONS IN GHANA: DISCOURSE ON COLONIAL LEGACIES AND CULTURAL NORMS
}

\author{
Dr. Obaapanin Adu Oforiwaa \\ University of Education, Winneba \\ P.O Box 25 \\ Winneba
}

\begin{abstract}
This study addresses the fundamental question of the under representation of women in higher education institutions in Ghana. The paper employed the qualitative research method to interrogate and understand beyond the statistics how the legacies of Colonialism have impacted the lives of female academics. Using a post-colonial theoretical lens, this paper explores the experiences of senior female academics by analyzing their perspectives on underrepresentation offemales within public universities in Ghana. The study elicited information from 9 senior female academics within three Ghanaian public universities. A multiple case study design was adopted to provide a wider set of contexts in which to explore the research questions. The discussion in this paper produced knowledge that being a senior female academic was a struggle that has several gendered dimensions bequeathed through traditional Ghanaian practices as well as colonial vestiges that ensured the academy is male dominated. From the data discussed, this study argues that issues of postcolonial gender inequalities and the interface of cultural norms created gender tensions for women within higher education institutions and the wider society.
\end{abstract}

KEYWORDS:_Institutional colonialism, gender inequalities, higher education, post colonialism

\section{INTRODUCTION}

There is global literature on how colonial practices affected equal participation but the details of the lived experiences from childhood on the impact of colonialism have mostly not been explored. Within institutions of higher education, there is the need to interrogate and understand beyond the statistics how the legacies of Colonialism have impacted the lives of female academics. Research on women in higher education over the past decade (Prah, 2002; Mama, 2004; Apusigah, 2008; Adusah-Karikari, 2008; Ogbogu, 2009; Morley et al., 2010) have enhanced our understandings about higher education institutions in Africa. In relation to Ghana, Boateng (2018) provided knowledge that a significant factor that ensured women are marginalized within institutions of higher learning is the colonialists' conception of education being the preserve of men, which was handed down to African Universities. Although women now participate at the highest levels of $\mathrm{HE}$, there has not been a significant increase in the proportion of female senior academics as these colonialist conceptions affect their recognition and promotion.

Postcolonial feminists such as Mama, Amediume, Prah, Oyewumi have described Higher education in Africa, as an intellectual borrowing from Europe bequeathed through the processes 
of colonialism. The literature on education in Ghana, further explains that European merchants and religious groups introduced formal education which persisted until independence and beyond (Graham, 1971; McWilliam and Kwamena-Poh, 1975; Dei, 2002). According to the authors, the education provided under colonial rule was gendered and 'native girls' "were trained as good servants and housewives, but above all for the Lord” (Debrunner, 1967:149-150; Pfann, 1965:23). This, the authors argued was the beginning of the creation of gendered spaces in academia.

There are a number of policies adopted by governments and some institutions of higher education in sub-Saharan Africa to address gender inequality issues. In Ghana, several gender sensitive policy initiatives including the national gender policy adopted in 2015 have been implemented over the years. Initiatives include the establishment of the National Council on Women and Development (NCWD), and later the Ministry of Women and Children's Affairs, and the Domestic Violence and Victims Support Unit of the Ghana Police Service. Ghana has a gender policy that requires all public institutions to establish gender desks (Adzahlie-Mensah, 2014). The nation adopted the Domestic Violence Act in 2007, which offers strong protection against the violation of women and children in particular. Ghana presently has a Ministry of Gender and Social Protection. However, the practical actions taken within HEIs to address gender issues remain largely unknown. Some critics allude to the fact that the traditional subordination of women have translated into the underrepresentation of females in senior academic positions (Chabaya, Rembe and Wadesango, 2009; Morley et al., 2010). This calls for a qualitative analysis that uncovers critical dimensions of the under-representation of women in the academic life of Ghanaian HEIs.

\section{The problem}

Sixty years after independence, coupled with the current proliferation of higher education institutions in Ghana, it is not clear how gender stereotypes instantiated through established colonial practices have been addressed within their institutional cultures. Although women's efforts in academia are increasingly being recognized by governments, university councils and society at large, the extant literature is replete with arguments to the effect that women in universities across Africa continue to face many hardships, gender stereotypes and general discrimination in their day to day activities on campuses (Mama, 2003; Adusah-Karikari, 2008; Prah, 2013). The literature is rooted in the understanding of how education in Ghana is located within colonial codes of logic that marginalized opportunities for females (Oyewumi, 1997; Dunne \& Adzahlie -Mensah, 2016). Within that thinking, the tensions between cultural norms of gender inequality and career progression still pertains even when women have been able to navigate their 
way into institutions of higher education. This concurs with the inequalities that have pervaded access to higher education in Ghana.

This study therefore, sought to explore female academics perceptions of Higher education institutions as creations of colonial practices and its continuous manifestations in the modus operandi of these institutions.

\section{METHODS AND METHODOLOGY}

This study is overtly premised in discourses of gender and development that seek to challenge the colonially ordered cultural, structural and systemic marginalization of women within institutions. It is mostly influenced by postcolonial propositions and tensions relating to gender and development. My interest in adopting a postcolonial approach is influenced by the fact that institutions of higher education in Ghana, dates back to colonialism where females were deprivileged (Quartey, 2007). Philips (2011) pointed out that the epistemological origins of postcolonial theories are rooted in justice and fairness.

The study adopted the phenomenological approach to illuminate the lived experiences of the respondents. According to Lester (1999), phenomenological approaches are effective in bringing to the fore the experiences and perceptions of individuals from their own perspectives. This informed the choice of qualitative research methods for the study. Qualitative techniques are regarded as effective in obtaining insightful information as respondents participate in a semi structured interview (Stake, 2010). Its conduct requires using data collection instruments that are sensitive in bringing out underlying meanings during data collection and interpretation. In effect, the use of qualitative method in this study was aimed at facilitating the collection of adequate data. For this study, three universities were selected as the sample universities. In all nine (9) female professors were selected to participate in the study. The study adopted the purposive and convenience sampling technique to select the participating universities. According to Patton (1990), purposive sampling illustrates the characteristics of particular subgroups of interest. This was to ensure that more females were not selected from a particular institution so that, that particular university's views became dominant.

I adopted the multi-stage sampling technique which combined snowball and purposive sampling in selecting the respondents. In each of the selected universities a sample of three (3) female academics who have attained the rank of Professor or Associate Professor were selected as key participants. According to Schutt (2009) the multi-stage sampling method is the use of more than one sampling method to select respondents from one category in the population of the study. The Nine (9) female professors were selected through the purposive and snowball sampling method. Snowball is a non-probability sampling technique which permits study subjects to suggest future subjects for recruitment from among their peers. According to Patton, (2002), this is a technique for locating information-rich key informants or critical cases.

Interviews were used as the technique for data collection. Interviews, according to Dunne (2005) are flexible tools for gathering in-depth knowledge about a phenomenon. A semi- structured 
interview guide composed of twelve (12) open- ended questions was used to provide flexibility and allow unanticipated responses. Each interview session lasted for a minimum of one a half hours and a maximum of two hours. These were in-depth interviews which put emphasis on the richness of information from the female professors (Aaker, D.A; Day, G. S \& Kumar, V. (1995). According to Maykut and Morehouse (1994) using interviews as data collection strategies helps to move the respondent beyond the surface talk to a rich discussion of thoughts and feelings.

\section{FINDINGS AND ANALYSIS}

\section{Institutional Colonialism}

The analysis highlights the historically gendered nature of educational inequality, its foundation in colonial times in Ghana and its relevance to female under-representation in HEIs. Analyses of education in Africa often refer to the colonial legacies, insisting that the influence of colonialism in education has "proved impervious to change" (Harber, 2004:71). Several works highlight how colonial vestiges continue to define educational experiences (Dunne \& Adzahlie-Mensah, 2016; Adzahlie-Mensah, 2014; Adjei, 2007; Quartey, 2007; Dei, 2004). This includes the institutional gender regime that continues to operate in educational institutions. Two perspectives shared by the participants highlighted how higher education institutions have become necessarily colonizing for women.

According to the participants:

One thing you must know is that the kind of formal education started in Africa was not to be granted to females. The history of education in Ghana taught us that males were those who attended school. Girls learnt needle work and home science. Ours is not further education to higher levels. It was to prepare us to become good cooks etc. No wonder institutions of higher education are unwelcoming of females

... You know that colonial thinking permeates our social thinking even in some communities today. We were victims in those days and victims today. Many females never had the opportunity nor the support to enroll. It is a legacy or what I may call product or part of the absences of colonialism, not cultural, I will argue.

Here, the participants are reflecting the theorizations of post-colonial feminists such as Ifi Amadiume (2006) and Apusigah (2008). They have pointed to the ways that European colonization in Africa produced gendered spaces; and how the institutions of formal education created inequity. In their views, the under-representation of females in universities was occasioned by the ways in which colonialism introduced schooling by drawing lines of division between males and females and also informed the historical development of higher education in Ghana (Mama, 2003; Adams, 2006). This argument finds support in much of the literature on education in excolonies. More specifically, previous research in Ghana highlighted the subordination of females in schools and other educational institutions (Dunne and Adzahlie-Mensah, 2016; AdzahlieMensah, 2014; Dunne et al., 2005; Avotri et al., 2000; Colclough et al., 2000). This subordination of females has been consistently documented in the $20^{\text {th }}$ century, in the works of Pfann, (1965), Debrunner, (1967), Graham (1971) and McWilliam and Kwamena-Poh, (1975). 
British Journal of Education

Vol.8, Issue 6, pp.18-26, June 2020

Published by ECRTD- UK

Print ISSN: ISSN 2054-6351: Online ISSN: ISSN 2054-636X

Many of my participants' comments were informative concerning the ways in which cultural norms contributed to gender disparities and access that affected the representation of females.

Three typical perspectives were:

Although undocumented, there are cases where Universities refused to offer appointment to a young prospective female lecturer because she was pregnant at the time of the interview and there are other such examples

There is an accepted perception on campus that pregnancy is no disease and therefore women in such state require no special attention and consideration

They will always make sure there is a male Head Of Department (HOD). "But, the females will be running the errands for them" I will be doing the paper work, be doing the paper work in the office, I will be calling the students for a meeting and recording things and keeping the records but not as... not in control as H.O.D. That actually didn't deter me though cos I was

These concerns expressed by the participants above highlights the point that, the current challenge women face in $\mathrm{HE}$ is something that has been intrinsic to Western knowledge and the assumptions that informed their production within higher education institutions. Also, it highlights the ways that HEI's in Ghana continue to reflect male-dominated, patriarchal practices that have their origins in their development within colonial times. The above raises several gendered practices, in which males easily invoked being female to exclude women from the institution, or relegate them to subordinate, often administrative positions. These practices speak to the constraining effects of femaleness within some of the literature (Altbach, 2004; Luke, 2002; Roces \& Edwards, 2000). They highlight how traditions of practice within the HEI's introduced gender ideologies, which greatly restrict access and participation for women (Jayaweera, 1997; Luke, 2002). The consistent flattening of the social construction of gender to an essentialised biological difference within HEIs raises fundamental questions about the extent to which HEI's commitments to improving gender equity remains at the rhetoric level and the institutional will to make shifts in their entrenched patriarchal systems (Luke, 2000) still remains answered.

The observations of another participant confirm these tensions, and suggest that despite gender equality policies, institutional processes remain highly gendered:

as a woman you come into academia, you expect that when I get there am getting all the support, but unfortunately the structure or the structures means... but it isn't, it isn't that encouraging, it is not at all, we want to get there but we are not getting there. I think the structures should be welcoming anytime to women, ... they qualify,... when they can do the job, they shouldn't just brush women aside, that is when they always make the mistake.... (Participant \# 3)

Unwritten employment codes of gendered practice appear to have been sustained for a long while. In universities in Ghana these practices find mostly females in almost every office working as the secretary and / or being assigned other presumed 'female roles' such as ushering and sometimes serving refreshments at meetings. The University of Education, Winneba Basic Statistics for 2013/14 shows 157 females as typists and secretaries compared to just 67 males as either 
secretaries or junior clerical staff. Expressing her views on how the colonial vestiges have influenced the positioning of women in HEI, one of the participants said,

....the general attitude of employment in Ghana as gendered, sees more females doing more within a perceived women's role in the formal employment sectors.... careers that exist in secretarial duties are mostly availed to females. A few males in Ghana will be seen grossly involved in employment as secretaries. (Participant \#2)

A reciprocal gendered patterning was observed at the higher echelons of educational institutions. This is observed by another participant who explains it in historical terms:

For me the structures in the university are unwelcoming to females. Historically, HEIs have been the preserve of schooled men. It is not surprising that from 1948 till date only three females have had the opportunity to serve in the capacity of Vice Chancellors in all the 14 public HEI in Ghana.... Look around and see how many female drivers are on our campuses, how many buildings and students' accommodations are even named after female figures. This tells you a lot. (Participant \#5)

The effects of the colonial practice of defining schooling in ways that privilege maleness works into a system of statistical invisibility of females at all levels of education. By statistical invisibility, I mean fewer females in a male dominated higher education arena in Ghana. A Participant put this more pointedly in stating that:

Because we are not wanted, we are not too many...I was the only female among many males from training college and when I came to the university I was the only female among my colleagues. Now I am the only female Professor in this faculty. .... (Participant \# 6)

Although the numbers of female professors have since increased in recent times, it is far from gender parity at the higher education level (Morley et al., 2010; MOE, 2016). The critical challenge posed by this invisibility is described by Acker (1994) that being the only female faculty in a department in a university makes one paradoxically both invisible and extra visible. The effects of a highly gendered institution are multiple and ultimately lead to the absence of senior female academics in the top academic positions. Their isolation brings with it associated disadvantages that includes lack of informal support systems that are important for inducting academics into the reward system, enhancing reputations and status and for career progress. The persistence of the colonial structures and processes in education have been highlighted by other researchers who described them as rather static institutions that remain entrenched in ex-colonies. Also, education ministry officials continue to be resistant to the suggestion of changes that appear to offer anything less rigidly defined (Harber, 2004; London, 2002; Moletno et al., 2000). According to the research participants, it is these conditions that frame the possibilities of their life experiences in academia as well as their career progression. 


\section{CONCLUSION}

The study revealed that the influence of colonial gender codes in privileging male education and the gendered practices within HEIs have produced the reality of under-representation of females. In addition, the persistence of initial colonial frames of logic, codes of school organization and curriculum organization created spaces of exclusion, marginalization and institutional subordination of females.

\section{Recommendations}

Within the context of this research's findings, it is recommended that:

- Ghanaian public universities need to make conscious efforts to produce more senior female academics.

- Ghanaian higher education Institutions will need to challenge the persistent institutional misogyny. By so doing, institutionalised cultural barriers to the academic enlistment and career progression of female academics have to be challenged and removed.

- Ghanaian Higher education institutions must invest in recruiting and supporting the development of female academics career progression. From a post-colonial theory perspective, increasing the numbers of senior female academics will be emancipatory both in decolonizing the academic and social spaces, and in validating the status of universities as knowledge generating centres where stereotypes are challenged, and normalcy is reconstructed.

\section{References}

Aaker, D.A., Kumar, V. \& Day, G.S. (1995). Marketing Research. Fifth edition. Wiley: New York

Adjei, P. B. (2007). Decolonising Knowledge Production: The Pedagogic Relevance of Gandhian Satyagraha to Schooling and Education in Ghana. Canadian Journal of Education, 30 (4), 1046-1067.

Adusah-Karikari, A. (2008). Experiences of Women in Higher Education: A study of women Faculty and Administrators in selected Public Universities in Ghana, Doctoral thesis, unpublished.

Adzahlie-Mensah, V. (2014). 'Being 'nobodies': school regimes and student identities in Ghana'. Unpublished $\mathrm{PhD}$ thesis, University of Sussex, UK.

Altbach, P.G. (2004). The costs and benefits of world-class universities'. Academe 90 (1):pp. 1-5 Apusigah, A. (2008). Is gender yet another colonial project? A critique of Oyeronke Oyewumi’s proposal. African Journal of Philosophy / Revue Africaine de Philosophie $X X$, pp.23-4.

Avotri, R., Owusu-Darko, L., Eghan, H. \& Ocansey, S. (2000) Gender and Primary Schooling in Ghana. Research Report No. 37. Brighton: IDS/FAWE

Boateng, D. A. (2018). Experiences of female academics in Ghana: negotiation and strengths as strategies for successful careers. African Journal of Social Work, 8.1.

Chabaya, O., Rembe, S., Wadesango, N. (2009). The persistence of gender inequality in Zimbabwe: Factors that impede the advancement of women into leadership positions in primary schools. South African Journal of Education, 29: 235-251. 
Coclough, C., Rose, P. \& Tembon, M. (2000). Gender inequalities in primary schooling: the roles of poverty and adverse cultural practice. International Journal of EducationalDevelopment 20 (1): $5-27$

Debrunner, H. W. (1967). A History of Christianity in Ghana. Accra: Waterville Publishing House, 1967

Dei, G. J. S. (2004). Schooling and education in Africa: The case of Ghana. Trenton: Africa

World Press, Inc.

Dunne, M. \& Adzahlie-Mensah, V. (2016). Subordinate subjects: the work of the hidden curriculum in post-colonial Ghana. In D. Wyse, L. Hayford, \& J Pandya (Eds). The SAGE handbook of curriculum pedagogy \&assessment.

Dunne, M., Pryor, J. \& Yates, P. (2005). Becoming a Researcher: a research companion for the social science. Maidenhead: Open University Press

Graham, C. K. (1971). The history of education in Ghana: from the earliest times to the declaration of independence. London: F. Cass.

Harber, C. (2004). Schooling as Violence: How schools harm pupils and societies.

Falmer: Routledge

Jayaweera, S. (1997). Women, education, and empowerment in Asia. Gender and Education, 9, 411-424. doi:10.1080/09540259721169

Lester, S. (1999). An Introduction to Phenomenological Research. Taunton UK: Stan Lester Developments. http//www.sld.Demon.co.uk/resmethy.pdf. Retrieved December, 22015

Luke, C. (2002). Globalisation and women in Southeast Asian higher education management. Teachers College Record, 104, 625-662.

Mama, A. (2003). Restore, Reform but do not transform: The gender politics of higher education in Africa, JHEA/RESA 1, (1), pp.101-125.

Mama, A. (2004). Critical Capacities: Facing the Challenges of Intellectual Development, Inaugural Lecture, Prince Claus Chair in Development and Equity, Institute of African Studies, http://web.uct.ac.za/org/agi/pubs/amina.htm. Retrieved on 1st August, 2014.

Maykut, P. \& Morehouse, R. (1994). Beginning qualitative research, a philosophic and practical guide. London: The Falmer Press.

McWilliam, H. O. A. \& Kwamena-Poh, M. (1975). The development of education in Ghana. Hong Kong: Longman Group.

Morley, L., Leach, F., Lussier, K., Lihamba, A., Mwaipopo, R., Forde, D. \& Egbenya, G. (2010). Widening Participation in Higher Education in Ghana and Tanzania: Developing an Equity Scorecard. An ESRC/DFID Poverty Reduction Programme Research Project, draft Research Report.

Ogbogu, C. (2009). An analysis of female research productivity in Nigerian universities. Journal of higher education policy and management, 31 (1): 17-22.

Oyewùmí, O. (1997). The invention of women: Making an African sense of Western gender discourses. Minneapolis: University of Minnesota Press.

Oyewumi, O. (2003). The white woman's burden: African women in Western discourse. In Oyewumi, Oyeronke ed. African women \& feminism: Reflecting on the politics of sisterhood. Trenton, Africa World Press. 
Patton, M. (1990). Qualitative evaluation and research methods (pp. 169-186). Beverly Hills,CA: Sage

Patton, M. (2002). Qualitative Research and Evaluation Methods, (3rd ed.), p. 295, Thousand Oaks, Sage Publications, California.

Pfann, H. (1965). A Short History of Christianity in Ghana. Cape Coast: Catholic Mission Press

Philips S. D. (2011). Implementing self-concept: matching, developing and deciding. In P. J Hartung \& L. M. Subich (Eds), Developing self in work \& career: concepts, cases, and contexts (pp.161-173), Washington, DC: APA

Prah, M. (2002). Gender Issues in Ghanaian Tertiary Institutions: Women Academics and Administrators at Cape-Coast University. Ghana Studies 5.

Prah, M. (2013). Through a woman's eyes: A version of events. Inaugural lecture presented at the University of Cape Coast on the attainment of Professoriate, November 2013

Quartey, S. (2007). Missionary Practices on the Gold Coast, 1832-1895. Youngstown, New York: Cambria Press.

Roces, M. \& Edwards, L. (2000). Contesting gender narratives, 1970-2000. In Edwards, L. \& Roces, M. (Eds.), Women in Asia: Tradition, modernity \& globalization. 1-15. Ann Arbor, MI: The University of Michigan Press.

Schutt, R.K. ( 2009). Investigating the Social World: The Process and Practice of Research. 6th edn . Thousand Oaks, CA: Pine Forge Press/Sage

Stake, E. R. (2010). Qualitative Research: Studying how things work, The Guildford Press 